ISSN: 1858-4837; E-ISSN: 2598-019X

Volume 15, Nomor 1 (2020),

https://jurnal.uns.ac.id/region

DOI: 10.20961/region.v1511.27002

\title{
Pengaruh perkembangan kampus terpadu UII terhadap permukiman di sekitarnya
}

The influence of the UII campus development on the surrounding settlement

\author{
F Ambraini ${ }^{1}$, D F Swasto ${ }^{1}$, and D H Rahmi ${ }^{1}$ \\ ${ }^{1}$ Departemen Teknik Arsitektur dan Perencanaan, Fakultas Teknik, UGM
}

Corresponding author's email: oja.ambraini@gmail.com

\begin{abstract}
Abstrak. Kampus merupakan suatu perkumpulan tersendiri yang terbukti mampu menjadi instrumen pemicu perkembangan wilayah. Salah satunya adalah Kampus Terpadu Universitas Islam Indonesia (UII) Yogyakarta. Pembangunan kampus terpadu UII berpengaruh terhadap pemkembangan permukiman di sekitar kampus, berupa pertumbuhan jumlah pelayanan dan jasa baik itu berupa indekos, cafetaria dan rumah makan pada sekitar kampus. Tujuan dari penelitian ini adalah untuk mengetahui perkembangan kawasan permukiman di sekitar kampus terpadu UII dan faktor-faktor yang mempengaruhinya. Penelitian ini menggunakan teknik analisis deskriptif kualitatif dengan data yang berasal dari hasil observasi dan wawancara. Hasil dari penelitian ini menunjukkan bahwa kebijakan pemerintah, perkembangan dan pembangunan kampus UII, dan mahasiswa yang bermukim di sekitar kampus merupakan faktor-faktor yang mempengaruhi perkembangan permukiman disekitar kampus UII. Hasil penelitian juga menunjukkan kawasan permukiman yang mengalami perkembangan terbesar adalah Dusun Lodadi, Dusun Kimpulan, dan Dusun Nglanjaran, yang berbatasan langsung dengan kampus terpadu UII.
\end{abstract}

Kata Kunci: Deskriptif Kualitatif; Mahasiswa; Perkembangan Kampus; Permukiman; Universitas

Abstract. Campus is a separate association that proved to be the determining factor of regional growth. One of them is the Integrated Campus of the Indonesian Islamic University in Yogyakarta. Development of an integrated campus UII affect the development of settlements around the campus, in the form of a growing number of services, such as boarding houses, cafeterias, and restaurants around the campus. The purpose of this study is to determine the development of the settlements area 
around the UII campus and factors influence it. This study uses descriptive qualitative analysis based on observations and interviews data. The results of this study indicate that government policy; the development and construction of the UII campus; and students who live around the campus are factors that influence the development of settlements around the UII campus. The results also showed that Dusun Lodadi, Dusun Kimpulan, dan Dusun Nglanjaran, which directly adjacent to the UII integrated campus, are residential areas that experienced the greatest growth.

Keywords: Campus Development; Descriptive Qualitative; Scholar; Settlement; University

\section{Pendahuluan}

Kota Yogyakarta sudah dikenal baik sebagai kota pendidikan dan pariwisata. Hal ini berdampak secara langsung menyebabkan tingginya tingkat urbanisasi yang mendorong peningkatan jumlah kegiatan serta kebutuhan ruang yang lebih luas. Keterbatasan ruang serta lahan yang tersedia di kota semakin sempit, sehingga mengakibatkan terjadinya perubahan penggunaan lahan di daerah pinggiran Kota Yogyakarta. Perubahan penggunaan lahan tersebut salah satunya dipicu oleh dibangunnya beberapa fasilitas pendidikan, seperti pembangunan Kampus Terpadu Universitas Islam Indonesia (UII).

Kampus Terpadu UII terletak di Kecamatan Ngaglik, Kabupaten Sleman, Provinsi Daerah Istimewa Yogyakarta (DIY) mulai dibangun pada tahun 1992. Keberadaan Kampus UII dan civitas akademik didalamnya membutuhkan pelayanan jasa pendukung dari kawasan sekitarnya. Pelayanan tersebut dapat berupa pelayanan rumah tinggal sementara atau hunian indekos, rumah makan, fotokopi, binatu, dan jasa pendukung lainnya. Tingginya kebutuhan civitas akademik, terutama mahasiswa, terhadap jasa pelayanan pendukung, membuka peluang bagi masyarakat yang tinggal di sekitar kampus untuk memperoleh penghasilan tambahan melalui penyewaan kamar atau rumah, maupun jasa pendukung lainnya. Peluang ekonomi ini selanjutnya mendorong perubahan penggunaan lahan di sekitar kampus terpadu UII, sekaligus merubah struktur ekonomi masyarakat. Perkembangan ini terjadi secara signifikan mulai dari tahun 1992 hingga sekarang 2018.

Huisman [1] menyatakan bahwa pelayanan sosial yang umumnya memiliki arti segala pelayanan yang di berikan oleh pemerintah dan di maksudkan untuk memperbaiki tingkat kehidupan penduduk. Pelayanan pendidikan adalah salah satu contoh dari pelayanan sosial. Salah satu kegiatan pelayanan yang menjadi perhatian pada penelitian ini adalah tentang keberadaan rumah-rumah multifungsi baik berbentuk rumah hunian indekos yang bergabung dengan rumah penduduk serta rumah yang bergabung dengan fasilitas pelayanan dan jasa. Seiring dengan perkembangan zaman fungsi rumah ikut berkembang baik berupa jenis, bentuk, ukuran serta fungsi ikut berkembang. Dari segi fungsinya dimana fungsi rumah sebagai tempat tinggal, saat ini telah banyak berubah fungsinya sebagai tempat usaha.

Kustiawan [2] mengatakan proses pergeseran penggunaan lahan dapat meliputi proses konversi alih fungsi, persebaran atau perluasan lahan. Konversi yang dimaksud adalah alih 
fungsi lahan yang menyangkut transformasi dalam pengalokasian sumber daya lahan dari suatu penggunanaan ke penggunaan lainnya dari suatu waktu ke waktu lainnya. Anwar [3] mengkaitkan perubahan guna lahan dengan faktor penduduk dan ekonomi. Pergeseran penggunaan lahan dapat didorong karena adanya peningkatan jumlah penduduk dan lahan yang tersedia semakin sedikit serta sulitnya mencari perkerjaan. Keadaan yang seperti ini pada akhirnya membuat masyarakat berusaha mengupayakan pemanfaaatan lahan yang mereka miliki secara semaksimal mungkin. Salah satu pemanfaatan lahan dan rumah tersebut dengan menjadikan rumah sebagai tempat usaha dengan tujuan penunjang penghasilan mereka. Dengan demikian terjadilah perubahan fungsi rumah mereka. Seiring dengan perubahan fungsi ini terjadi pula penyesuaian-penyesuaian terhadap rumah, sehingga rumah tidak lagi hanya sebagai tempat tinggal saja, tetapi menjadi bangunan yang multi fungsi sebagai tempat usaha.

Penelitian ini memiliki kebaharuan dibandingkan penelitian-penelitian yang sudah ada sebelumnya. Penelitian sebelumnya hanya menitikberatkan substansi kajian pada perubahan kepemilikan bangunan dan harga tanah [4] serta perkembangan spasial permukiman pada kawasan di sekitara kampus Perguruan Tinggi [5]. Kebaharuan penelitian ini ditunjukkan melalui tujuan yang ingin dicapai dalam penelitian ini adalah untuk mengetahui perkembangan kawasan permukiman di sekitar kampus terpadu UII dan faktor-faktor yang mempengaruhinya.

\section{Metode penelitian}

Metode penelitian yang digunakan pada penelitian ini adalah deduktif kualitatif dengan menggunakan peta citra sebagai alat bantu dalam melakukan analisis. Menurut Moleong [6], penelitian dengan metode kualitatif adalah penelitian yang bermaksud untuk memahami fenomena tentang apa yang dialami oleh subjek penelitian misalnya perilaku, persepsi, motivasi, tindakan dan lain-lain secara holistik dan dengan cara deskripsi dalam bentuk katakata dan bahasa pada suatu konteks khusus yang alamiah dengan memanfaatkan berbagai metode ilmiah. Selanjutnya Moleong juga mengemukakan bahwa penelitian kualitatif dapat dimanfaatkan untuk meneliti sesuatu dari segi prosesnya [6].

Penelitian kualitatif yang mengandalkan manusia sebagai alat penelitian dalam usaha menemukan teori-teori dasar yang bersifat deskriptif. Proses penelitian yang dilakukan dalam penelitian ini yaitu meliputi tahapan pengumpulan data melalui observasi, wawancara, dan dokumentasi. Proses analisis data dan mengkonstruksi hasil analisis untuk menggambarkan perkembangan permukiman di sekitar Kampus Terpadu Universitas Islam Indonesia dan tanggapan masyarakat terhadap perkembangan permukiman pada kawasan sekitar kampus terpadu tersebut. Analisis data dalam penelitian ini dilakukan secara spasial dengan menggunakan teknik overlay menggunakan software Arc GIS 10.2 dan Coreldraw X7 dengan berlandaskan peta Google Maps dan peta citra satelit terhadap peta penggunaan lahan di kawasan sekitar Kampus Terpadu Universitas Islam Indonesia khususnya pada permukiman yang berdekatan serta berbatasan secara langsung dengan kawasan kampus terpadu tersebut. Secara time series dengan rentang waktu 10 tahun dari tahun 2007 hingga 2017 dengan menggunakan peta time series Google Maps dan 1990 hingga 2017 dengan 
memperoleh data kualitatif dari masyarakat sekitar untuk memperoleh data perkembangan permukiman serta perubahan penggunaan lahan sekitar. Analisis data selanjutnya dilakukan dengan menggunakan kerangka teori yang bersumber dari berbagai teori yang ada sebagai acuan dalam melakukan observasi lapangan guna untuk mengidentifikasi dan menjelaskan faktor yang mempengaruhi perubahan penggunaan lahan di kawasan sekitar Kampus Terpadu Universitas Islam Indonesia.

Tabel 1. Variabel penelitian.

\begin{tabular}{|c|c|c|}
\hline Sasaran Penelitian & Variabel & Indikator \\
\hline $\begin{array}{l}\text { Mengidentifikasi } \\
\text { perkembangan kawasan } \\
\text { permukiman di sekitar kampus } \\
\text { terpadu UII }\end{array}$ & $\begin{array}{l}\text { perkembangan kawasan } \\
\text { permukiman di sekitar kampus } \\
\text { terpadu UII }\end{array}$ & $\begin{array}{ll}\text { - } & \text { Tahap-tahap perkembangan } \\
\text { kawasan permukiman di } \\
\text { sekitar kampus terpadu UII } \\
\text { - } \quad \text { Masyarakat asli } \\
\text { - } \quad \text { Unit informasi UII } \\
\text { - } & \text { Pemanfaatan lahan }\end{array}$ \\
\hline $\begin{array}{l}\text { Mengidentifikasi faktor-faktor } \\
\text { yang mempengaruhi } \\
\text { perkembangan permukiman di } \\
\text { dusun sekitar kampus terpadu } \\
\text { UII }\end{array}$ & $\begin{array}{l}\text { Faktor-faktor yang } \\
\text { mempengaruhi perkembangan } \\
\text { permukiman di dusun sekitar } \\
\text { kampus terpadu UII }\end{array}$ & $\begin{array}{ll}\text { - } & \text { Faktor kebijakan } \\
& \text { Pemerintah } \\
\text { - } & \text { Faktor pembangunan } \\
& \text { kampus UII } \\
\text { - } & \text { Sejarah pembentukan } \\
& \text { dusun } \\
\text { - } & \text { Masyarakat asli } \\
\text { - } & \text { Mahasiswa (alasan } \\
& \text { mahasiswa memilih indekos } \\
\text { - } & \text { Hunian sementara (indekos) }\end{array}$ \\
\hline
\end{tabular}

Tabel 1 merupakan landasan penulis untuk mendapatkan berbagai informasi dari berbagai macam sumber informan, sumber informan berasal dari mahasiswa dan masyarakat sekitar dan sumber informan dari institusi kampus (dosen dan pegawai) yang telah lama berkerja di kawasan UII.

\section{Analisis dan pembahasan}

\subsection{Perkembangan fisik kampus UII}

Perkembangan spasial Kampus Terpadu UII dapat dilihat dari kepadatan serta kerapatan antar rumah penduduk yang begitu padat, perkembangan ini dapat dilihat dari proses pertumbuhan permukiman yang terjadi sejak tahun 1990-an hingga 2018. Dusun Lodadi telah berdiri jauh dari sebelum keberadaan Kampus Terpadu UII. Hal ini dapat dilihat pada gambar 1 dimana keberadaan Dusun Lodadi telah ada terlebih dahulu dibanding Kampus UII dikarenakan posisinya berhadapan langsung dengan Jalan Kaliurang $\mathrm{Km} \mathrm{14,5}$. Laju perkembangan permukiman ini sangatlah cepat dibandingkan dengan dusun yang lainnya. Perkembangan permukiman di dusun sekitar kampus UII terjadi menjadi lima kategori yakni dengan tahap 1, tahap 2, tahap 3 tahap 4, perkembangan dusun ini juga dipengaruhi terhadap tahap penambahan gedung fakultas pada Kampus UII. Berikut adalah 
perkembangan Kampus UII dalam periode awal pembangunan tahun 1990 dan sampai saat 2018:
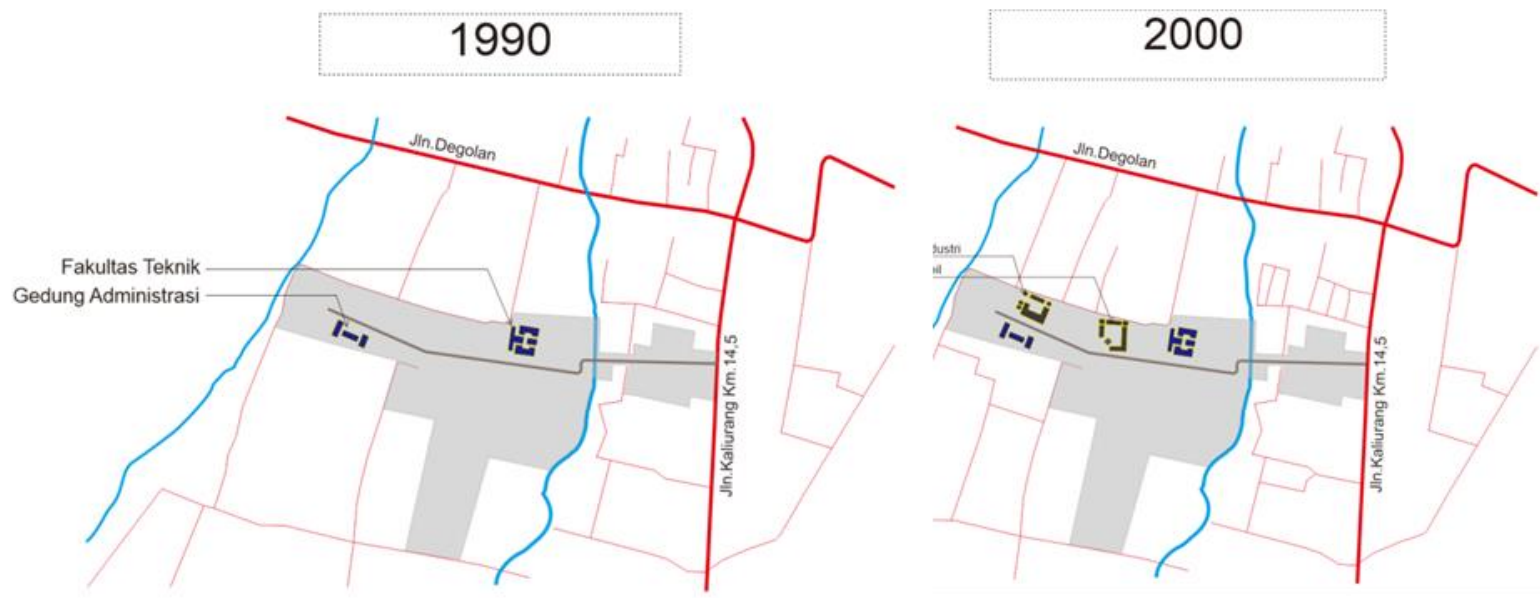

Gambar 1. Peta pembangunan gedung pertama pada kawasan kampus terpadu UII tahun 1990-2000.

Perkembangan permukiman di sekitar UII pada tahun 1990 (Gambar 1) lebih mengerucut kepada poros Jalan Kaliurang. Berdasarkan informasi dari masyarakat sekitar, pemondokan untuk memfasilitasi mahasiswa UII berawal dari inisiatif warga sekitar untuk menjadikan rumah mereka menjadi hunian sementara atau rumah sewa, ruang yang masih kosong dari bagian rumah masyarakat dibagi menjadi beberapa bilik kamar kos untuk di sewakan. Di awal pembangunan ini masih banyak lahan yang kosong serta indekos permanen belum banyak yang dibangun di daerah ini. Pembangunan Fakultas Teknik Sipil pada awalnya merupakan Fakultas Hukum UII. Namun dengan banyaknya jumlah mahasiswa Fakultas Hukum UII tidak dapat menampung jumlah mahasiswanya sehingga dijadikan Fakultas Teknik Sipil dan perencanaan yang pada awalnya berlokasi pada Kampus UII Cikditiro. Perencanaan pembangunan 2 gedung ini dimaksudkan untuk memberi batas patokan wilayah kampus UII, sehingga dibangun secara vertikal mengarah ke barat Kawasan Kampus UII. Pada awal tahun 2000-2010 UII memulai pembangunan secara signifikan. Mulai membangun Gedung Rektorat serta beberapa fakultas lainya. Pada tahap ini UII juga memulai pembangunan jalan paving blok yang mengelilingi kawasan UII sehingga dapat terlihat jelas garis patokan antara tanah milik warga dan milik Kampus Terpadu UII. Selanjutnya menjelaskan perkembangan kampus tahun 2000-an. 

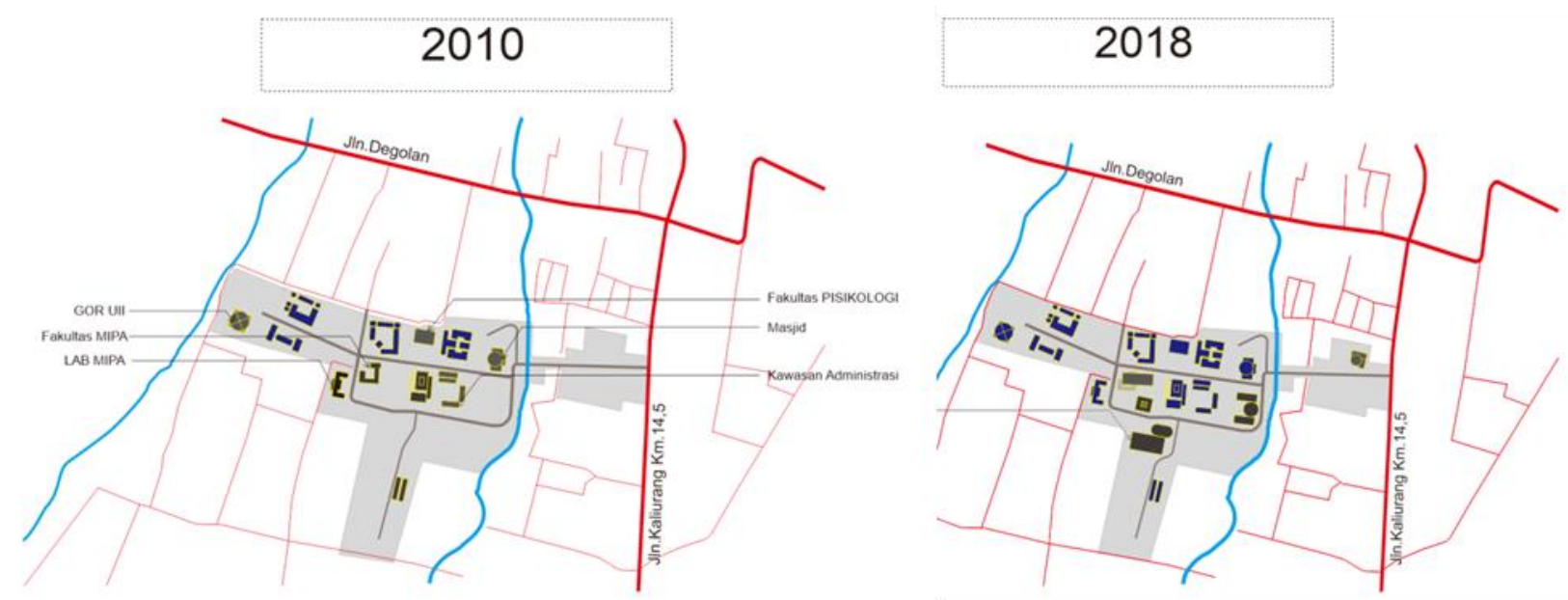

Gambar 2. Peta perkembangan kampus terpadu UII tahun 2010-2018

Pada awal tahun 2000-2010 perkembangan kampus UII terhadap fasilitas gedung fakultas semakin bertambah (Gambar 2). Hal ini juga dikarenakan dibukanya beberapa jurusan pada kawasan tersebut. Tingginya permintaan konsumen akan kebutuhan perkuliahan mempengaruhi UII terhadap pembangunan gedung-gedung baru demi menunjang kebutuhan fasilitas mahasiswanya. Pada awal tahun 2000 ini UII membangun beberapa fasilitas pendukung seperti Gedung Kahar Muzzakir dan Masjid Ulil Albab pada tahun 2004, pembangunan Gedung Olah Raga pada tahun 2005 serta mendirikan Fakultas IImu Pengetahuan Alam yang terbagi atas beberapa jurusan yakni Jurusan Farmasi, Jurusan Statistik, Jurusan Kimia dan Jurusan Matematika. Pada tahun 2000-an juga UII membangun Laboraturium Farmasi dan Gedung Jurusan Ilmu Komunikasi pada tahun 2007. Pada era pembangunan 2000 hingga 2010 ini berdampak terhadap perkembangan fisik kawasan di sekitarnya hal ini dikarenakan semakin banyaknya jumlah mahasiswa yang mendaftar maka akan semakin banyak akan kebutuhan fasilitas penyedia pelayanan dan jasa seperti rumah makan dan rumah sewa indekos.

Perkembangan pada tahun 2010 hingga 2018 (Gambar 3) UII kembali membangun beberapa gedung fakultas, salah satunya adalah Fakultas Hukum yang awalnya berada di Kawasan Cikditiro yang dipindahkan ke Kampus Terpadu UII di Jalan Kaliurang Km 14,5. Pembangunan gedung Fakultas Hukum ini terjadi pada tahun 2018 hingga sampai saat ini tahun 2019 masih dalam tahap pengerjaan. Pemindahan fakultas ini sangat berdampak terhadap pertumbuhan jumlah penyedia fasilitas pelayanan dan jasa terhadap mahasiswa. Pada tahun 2014, UII ditetapkan sebagai Universitas Terakreditasi A. Sehingga berpengaruh terhadap minat masyarakat dari berbagai daerah untuk menempuh masa studi pada Kampus Universitas Islam Indonesia. Pada perencanaan Masterplan UII dirancang memanjang ke arah timur hingga melewati batas sungai pada saat ini. Pada tahun 2011 UII membangun perpustakaan pusat yang di dalamnya ditemukan candi pada masa pembangunanya. Sehingga dapat menjadi objek wisata Candi Hindu pada gedung perpustakan pusat ini. 


\subsection{Perkembangan fisik dusun di sekitar kampus terpadu UII}

Terwujudnya permukiman sebagai bentuk fisik yang mempengaruhi beberapa faktor-faktor salah satunya faktor ekonomi, sosial realigi dan kultural. Unsur (faktor) sosiokultural yang paling dekat dengan aransemen lingkungan terbangun adalah aktivitas. Maka pembentukan fisik spasial permukiman berhubungan dengan aktivitas masyarakat. Permukiman merupakan kelompok satuan kediaman manusia pada suatu wilayah berupa bangunan rumah tinggal dan segala fasilitas yang diperlukan untuk menunjang kehidupan penghuninya [7].

Perkembangan permukiman tahap satu ini mayoritas rumah warga serta ladang persawahan yang terbagi 2 jenis, yaitu ladang kering (tanah tandus) dan ladang basah (persawahan). Pembangunan tahap 1 Kampus Terpadu UII dimulai dengan pembangunan Fakultas Teknik Sipil dan gedung perkuliahan yang terletak di depan kampus dan belakang kawasan kampus yang bersifat memanjang ke belakang. Perkembangan permukiman pada akhir tahun 1990an ini belum padat, dapat dilihat pada peta di bawah ini permukiman warga lebih cenderung mengarah ke Jalan Kaliurang Km 14,5. Perkembangan permukiman pada kawasan UII lebih mengacu terhadap Jalan Kaliurang dikarenakan fasilitas penyedia pelayanan dan jasa lebih mengacu terhadap Jalan Kaliurang sehingga dusun-dusun yang berada di sekitar jalan utama ini lebih padat hingga pada saat ini berdasarkan survey yang dilakukan terhadap masyarakat Dusun Lodadi:

"Awalnya berdiri Kampus Terpadu UII ini berawal pada tahun 1989 yang cuma satu gedung tok (Kampus Teknik) dan gedung di depan Fakutas Teknik Industri, dulu kan masih belum ada kost-an, masyarakat nawarin kamar mereka untuk di jadikan kosan. Lodadi ini bisa rame karena deket Jalan Kaliurang sama bersebelahan dengan pintu gerbang UII. Dulunya masih banyak petak sawah disini" [8]

Berdasarkan informasi yang diterima dari masyarakat dapat digambarkan pola permukiman yang masih belum terlalu padat di sekitar Kampus Terpadu UII, perkembangan permukiman lebih dipengaruhi terhadap keinginan mahasiswa yang ingin memilih tempat tinggal berdekatan dengan fasilitas penunjang mereka. Gambar 2 adalah gambaran peta yang mengambarkan kondisi UII pada saat tahun 1990.

Gambar 3 adalah gambaran sebaran permukiman pada kawasan dusun di sekitar Kampus UII. Data tersebut didapati oleh wawancara terhadap warga serta digambarkan kembali posisi rumah serta indekos yang ada di sekitar UII. Pada awal pembangunan Kampus Terpadu UII hanya terdapat 2 bangunan fakultas yakni Fakultas Teknik Industi dan Fakultas Teknik Sipil dan Perencanaan. Posisi bangunan yang memanjang membuat permukiman di belakangnya berkembang menjadi fasilitas penyedia pelayanan dan jasa. Namun dikarenakan posisi beberapa dusun di belakang kampus UII jauh dari jalan raya sehingga berpengaruh terhadap perkembangan permukiman di sekitar belakang kampus UII. Berbeda dengan dusun yang berada pada pada poros Jalan Kaliurang yang lebih padat dikarenakan fasilitas penyedia pelayanan dan jasa untuk mahasiswa yang lebih lengkap sehingga 
membuat beberapa dusun berada pada depan Kampus UII lebih cepat berkembang dibandingkan dusun yang berada di belakang Kampus UII.

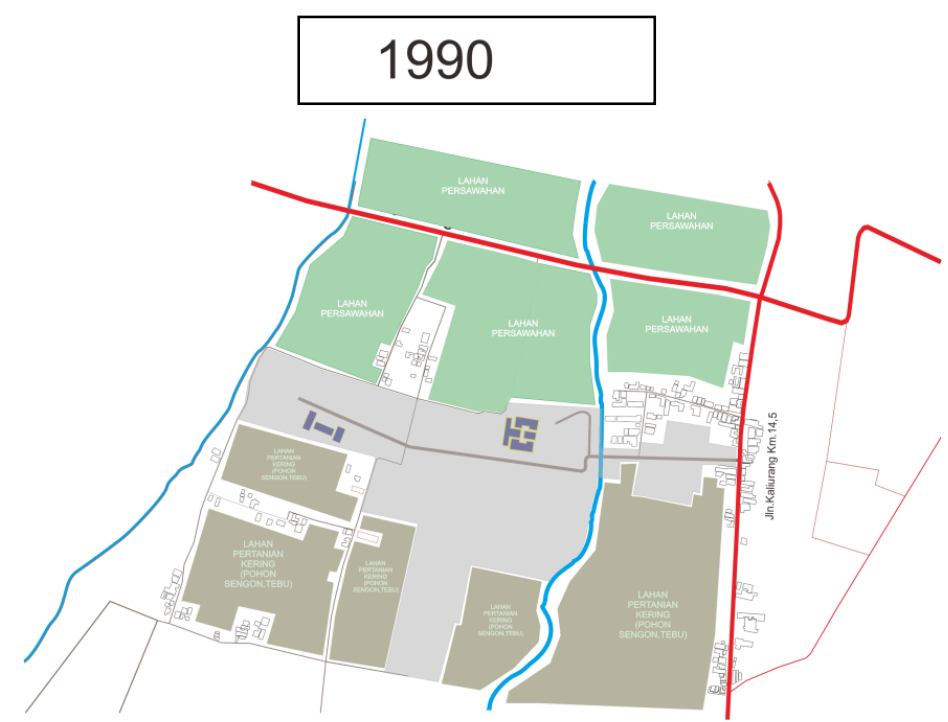

Gambar 3. Peta gambaran perkembangan permukiman di sekitar kampus UII tahun 19902000.

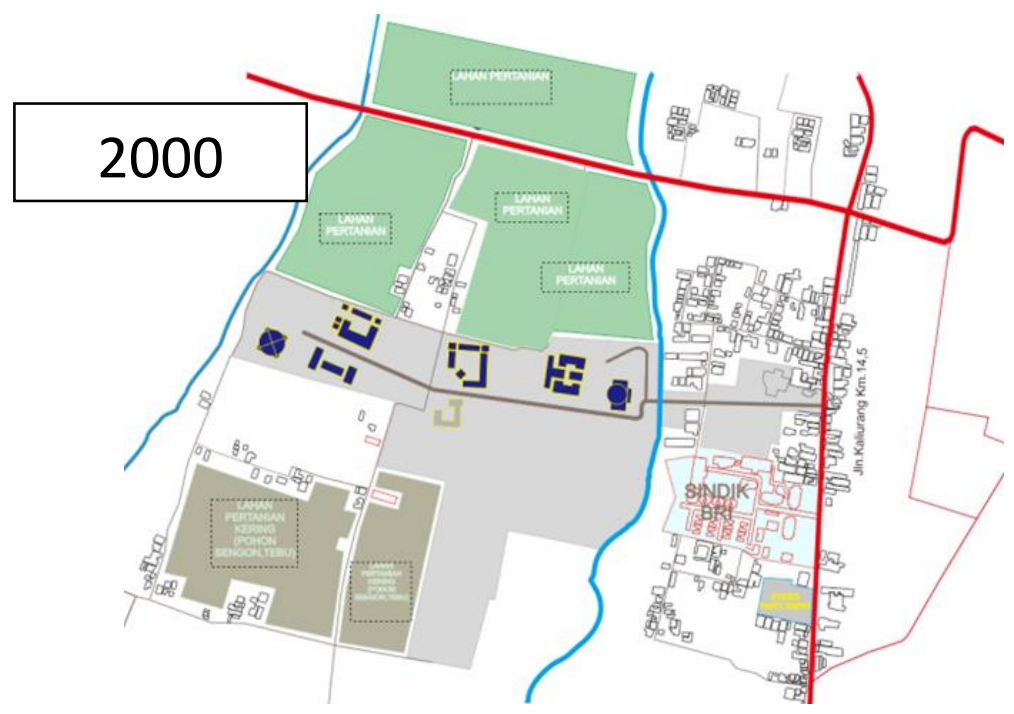

Gambar 4. Peta gambaran perkembangan permukiman di sekitar kampus UII tahun 2000.

Perkembangan permukiman pada tahun 2000-an ke atas ini terjadi perkembangan permukiman yang signifikan. Hal ini terjadi dengan bertambahnya berbagai fakultas di Kampus Terpadu UII permintaan pelayanan dan jasa pun mulai bertambah. Dengan bertambahnya mahasiswa maka kebutuhan terhadap tempat tinggal "indekos" ataupun warung makan serta pelayanan jasa semakin bertambah. Permukiman di sekitar Kampus UII pada masa ini telah berkembang dengan pesat seiring dengan bertambahnya jumlah mahasiswa Kampus Terpadu UII. Rumah indekos dan pelayanan dan jasa serta lainya tumbuh 
sangat pesat jika dibandingkan dengan rumah pribadi (rumah warga). Di dalam wawancara dengan beberapa warga khususnya di sekitar Kampus UII mereka (warga asli) justru lebih memilih mengalihkan fungsi rumah pribadi mereka dengan rumah indekos/warung/tempat fotokopi. Mereka merasa bahwa dengan merubah fungsi rumah mereka akan membantu menaikkan penghasilan perekonomian mereka jika dibandingkan dengan rumah pribadi. Pada tahun ini perkembangan permukiman sudah menjerumus di sekeliling kawasan Kampus Terpadu UII. Peningkatan ini terjadi secara signifikan pada tahun 2000-an hingga sampai saat ini. Perkembangan fisik pada kawasan dusun di sekitar UII pada tahun 2000 dipicu oleh dibangunnya beberapa fakultas yang dijelaskan pada sub-bab perkembangan Kampus UII.

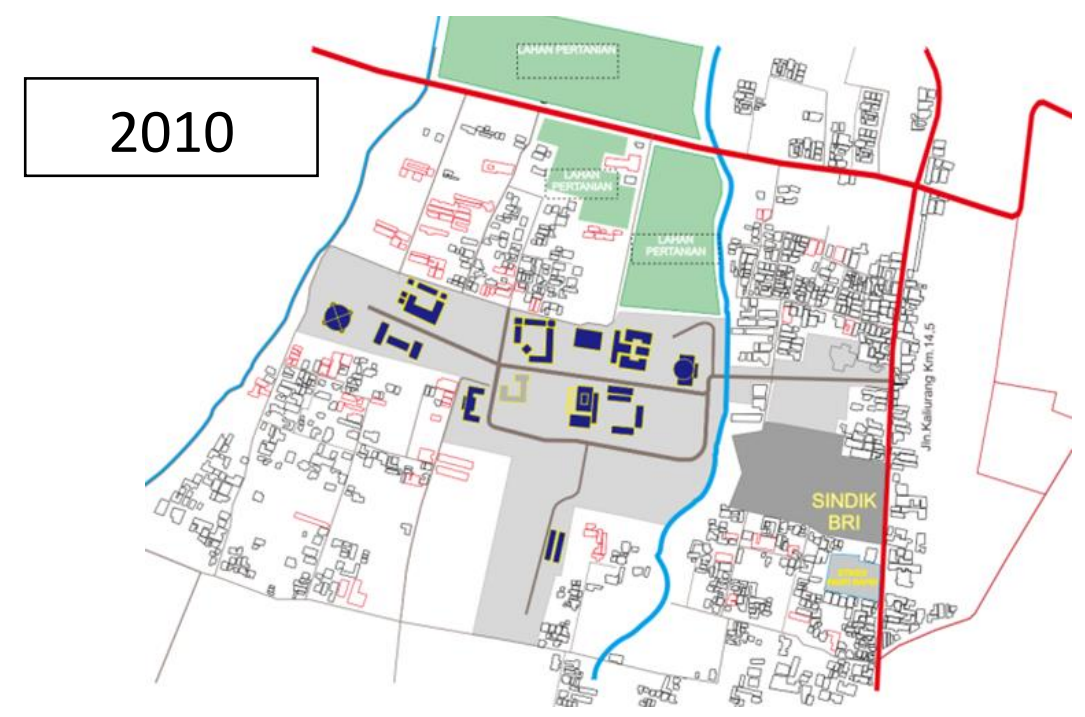

Gambar 5. Peta gambaran perkembangan permukiman di sekitar kampus UII tahun 2010.

Perkembangan fisik pada tahun 2000-2010 (lihat Gambar 5) lebih cenderung berkembang kepada beberapa dusun di belakang Kampus UII. Hal ini dikarenakan masih banyaknya lahan kosong yang tersedia pada dusun di belakang kampus tersebut. Keterbatasan lahan pada dusun yang berada pada depan kampus UII membuat harga lahan yang semakin tinggi sehingga banyak investor yang ingin membangun pada lahan yang lebih luas sehingga lebih banyak mendapatkan ruang yang lebih luas. Perkembangan pada tahun 2010 ini dapat dilihat pada peta di atas yang menjelaskan bertambanya beberapa indekos ditandai dengan bangunan yang berwarna merah lebih didominasi oleh beberap dusun di belakang Kampus UII. Data tersebut di peroleh dari Google Map tahun 2005-2010 serta diolah kembali oleh penulis. 


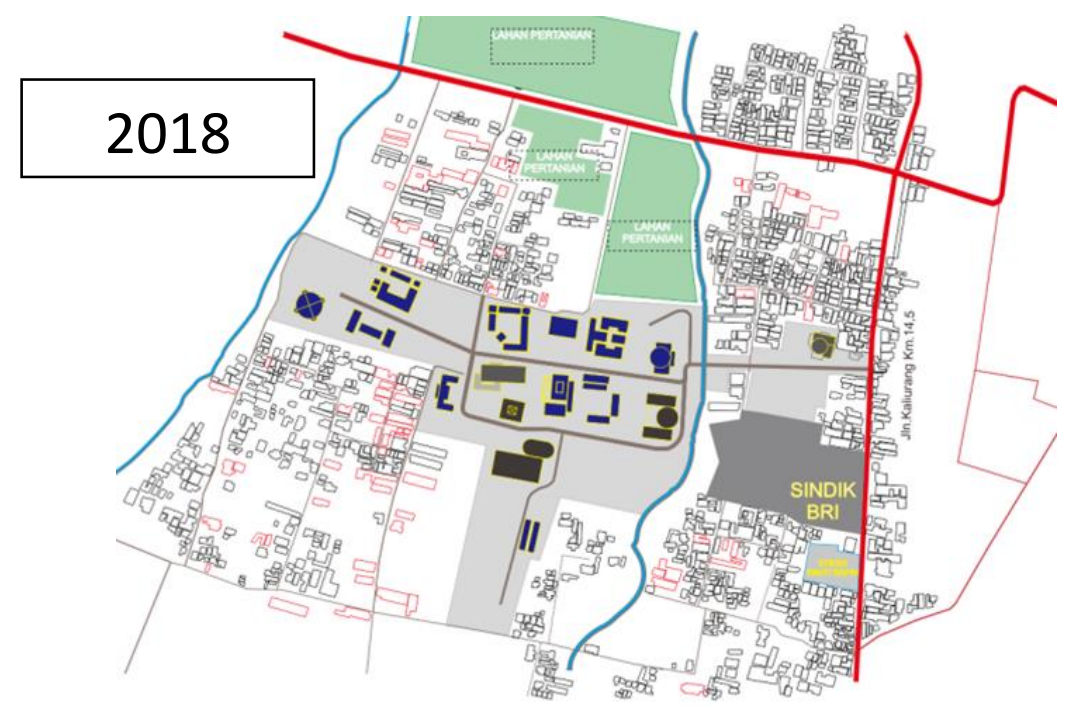

Gambar 6. Peta gambaran perkembangan permukiman di sekitar kampus UII tahun 2018.

Perkembangan fisik pada tahun 2010-2018 (lihat Gambar 6) lebih memadati kawasan belakang Kampus UII yakni pada Dusun Nglanjaran dan Dusun Kimpulan. Pemadatan fisik kawasan ini dipengaruhi oleh beberapa hal yakni pemindahan Fakultas Hukum dari Kampus Hukum Taman Siswa menuju Kampus Terpadu UII. Serta perolehan akreditasi UII oleh BANPT pada tahun 2014 meraih peringkat A. Sehingga semakin banyaknya calon mahasiswa dari berbagai daerah yang ingin menempuh studi pada Kampus UII. Penambahan jumlah indekos ini dapat dilihat pada peta di bawah ini terlihat beberapa bangunan bertampah pada dusun di belakang UII. Perkembangan ini juga dipicu oleh bertambahnya beberapa fasilitas penyedia pelayanan dan jasa pada kawasan belakang Kampus UII sehingga mahasiswa tidak lagi terpaku oleh Jalan Kaliurang untuk mencari kebutuhan sehari-hari mereka seperti mencari makanan, laundry dan lainya.

Lynch [9] dalam bukunya Site Planning yang menyatakan bahwa pada saat sekarang adalah periode pertumbuhan cepat dari beragam institusi diantaranya adalah kampus universitas, rumah sakit, unit pemerintahan dan pusat kebudayaan. Salah satunya penunjang perkembangan suatu daerah adalah kampus atau perguruan tinggi yang akan berkembang serta menimbulkan karakter yang kuat di dalamnya. Perguruan tinggi yang diletakan pada suatu daerah akan menunjang perkembangan di suatu daerah tersebut serta menimbulkan karakteristik yang kuat di dalamnya. Hal tersebut menjelaskan bahwa suatu institusi atau kampus di suatu wilayah akan mempengaruhi struktur ruang wilayah di sekitarnya untuk memfasilitasi serta menunjang segala macam aktifitas di dalamnya. Perkembangan permukiman pada kawasan sekitar Kampus UII membentuk pola-pola yang bersifat khusus di dalamnya. Terdapat pengelompokan permukiman yang di dalamnya terdapat permukiman dan penyedia fasilitas pelayanan dan jasa. 
3.3. Faktor-faktor yang mempengaruhi perubahan penggunaan lahan di sekitar kampus Terpadu UII

Lahan sebagai suatu sumber daya alam yang dimanfaatkan oleh seluruh masyarakat memiliki sadar yang dinamis. Artinya pada suatu saat akan mengalami perubahan. Perubahan penggunaan lahan merupakan suatu proses yang berjalan dengan seiring berkembangngnya jumlah serta aktivitas penduduk. Tidak tertutup kemungkinan juga perubahan fisik dampak dari pembangunan suatu institusi yang terpengaruhi oleh beberapa faktor di dalamnya. Berikut beberapa faktor yang mempengaruhi perkembangan permukiman di beberapa dusun di sekitar Kampus Terpadu UII:

3.3.1 Faktor kebijakan pemerintah yang menetapkan kawasan pertanian menjadi kawasan pendidikan dan permukiman. Perkembangan permukiman di wilayah pada kawasan Desa Umbulmartani dan Desa Sardonoharjo berawal dari keluarnya Izin Lokasi dari Gubemur Kepala Daerah Istimewa Yogyakarta No.593.82/2238 tanggal 30 Desember 1983. Kemudian tahun 1990 dimulai pembangunan Kampus Terpadu UII yang didahului tahap perencanaan. Pada perkembangan selanjutnya Masterplan Kampus Terpadu UII menyesuikan dengan RIP (Rencana Induk Pengembangan) Kampus UII yang dimuat dalam Rencana Tata Ruang kawasan Kampus Terpadu UII tahun 1995 dengan berpedoman pada RTRW Propinsi DIY tahun 1992 Dan RTRW Kabupaten Sleman tahun 1992. Dengan ditetapkanya peraturan tersebut berdampak terhadap perkembangan beberapa dusun di sekitarnya salah satunya Dusun Lodadi yang berubah menjadi kawasan pendidikan. Pada kawasan ini selain adanya perkembangan penduduk secara signifikan, tidak dapat dipungkiri bahwa keberadaan Kampus Terpadu UII telah memberi dampak yang signifikan terhadap permukiman sekitar. Lahan-lahan kosong di awal tahun 1980 sampai dengan 1990-an berubah menjadi lahan bermukim yang difungsikan sebagai tempat tinggal ataupun lahan komersil seperti warung, ruko, laundry warnet dan tempat fotokopi. Perubahan ini dapat dilihat dari transformasi pola permukiman di Jalan Kaliurang Km 14,5 dari tahun 1980 hingga 2016 dimana lahan-lahan kosong berubah menjadi lahan bermukim serta pertokoan pelayanan dan jasa. Perkembangan dari berbagai macam kegiatan desa di atas tentunya disertai perubahan penggunaan lahan. Perubahan itu sendiri dipengaruhi oleh berbagai faktor diantaranya kegiatan kampus, aksebilitas dan kondisi wilayahnya. Diagram kebijakan pemerintah yang berpengaruh terhadap perubahan penggunaan lahan pada kawasan UII dapat dilihat pada Gambar 7. 
3.3.2. Faktor perkembangan dan pembangunan kampus UII. UII pada awalnya bernama Sekolah Tinggi Islam (STI), didirikan oleh beberapa tokoh nasional seperti Dr. Mohammad Hatta, KH. Abdulkahar Mudzakkir, Moh. Roem, KH. A. Wahid Hasyim, KH. Mas Mansyur dan Moh. Natsir serta tokoh lainnya di Jakarta pada 8 Juli 1945. STI menjadi pendidikan tinggi nasional pertama di Indonesia yang kemudian berubah status menjadi universitas dan bernama Universitas Islam Indonesia pada 3 November 1947.

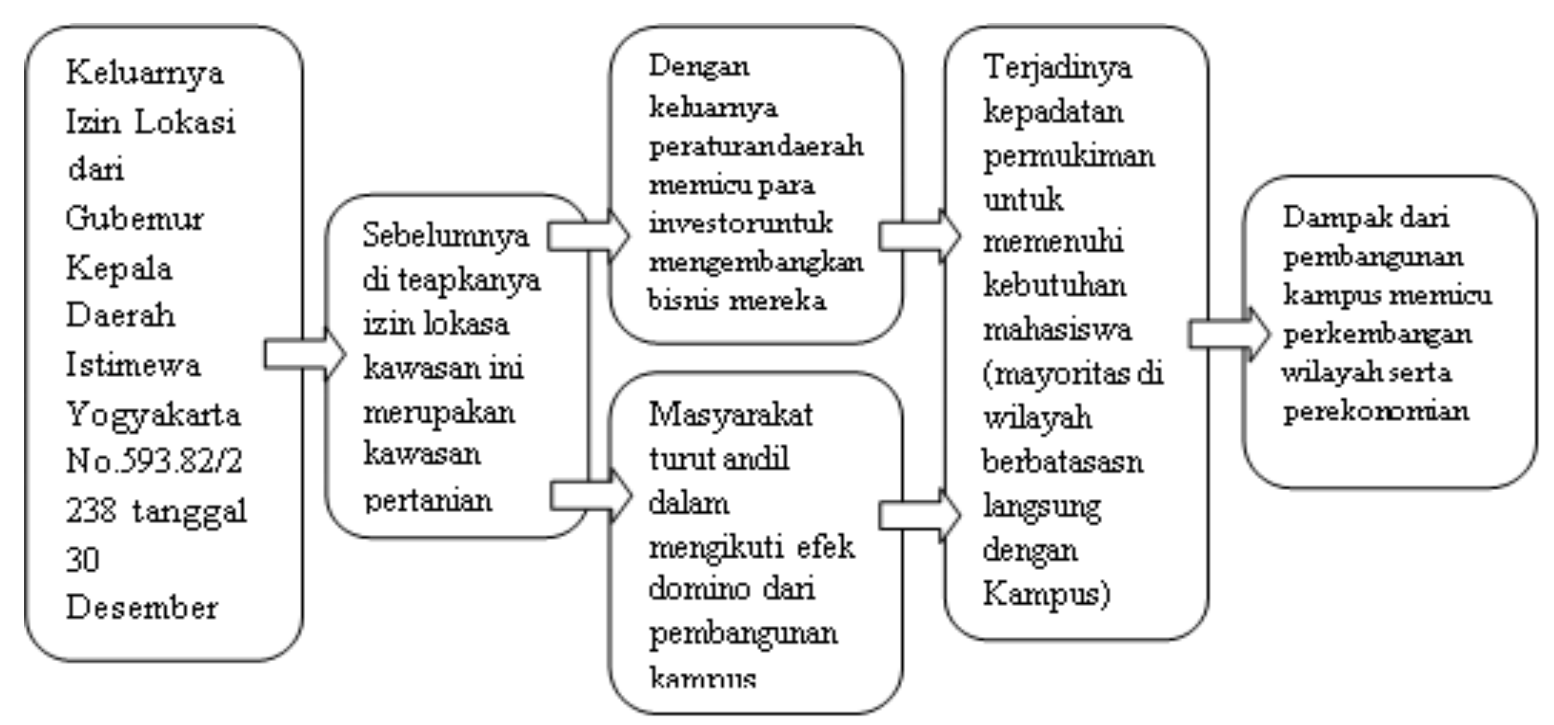

Gambar 7. Faktor kebijakan pemerintah terhadap pengembangan kawasan.

Pada tahun akademik 2017/2018, UII memiliki 8 (delapan) fakultas, dengan 4 (empat) program Diploma Tiga, 24 (dua puluh empat) program Sarjana, 5 (lima) program Profesi, 10 (sepuluh) program Magister dan 3 (tiga) program Doktor. Ull telah terakreditasi institusi $A$ dan sebagian besar dari program studi di UII telah mendapat akreditasi A dan B dari Badan Akreditasi Nasional Perguruan Tinggi (BAN-PT). UII memiliki jumlah mahasiswa aktif lebih dari 23.000 mahasiswa. UII membangun Kampus Terpadu sejak tahun 1990 dengan lahan seluas 36 hektar di daerah sejuk di Jalan Kaliurang Km 14,5. Pengembangan terus dilakukan dengan dibangunya Fakultas Hukum yang sebelumnya berlokasi di Jl. Taman Siswa No. 158. Pemindahan ini berdampak terhadap perkembangan permukiman di sekitarnya termasuk penyedia fasilitas pelayanan dan jasa. Fasilitas penyedia seperti hunian sementara pada beberapa dusun di sekitar UII mengalami peningkatan jumlah pada tahun 2018. Hal ini dikarenakan isu pada tahun 2016 pemindahan Fakultas Hukum dari Jalan Tamansiswa ke Kampus Pusat UII. Isu ini berdampak terhadap penambahan jumlah indekos pada masing masing dusun terutama dusun yang berdekatan dengan Kampus Terpadu UII. Penambahan jumlah indekos ini dikarenakan penambahan jumlah masyarakat bermukim (mahasiswa) pada kawasan ini sehingga para investor yakin untuk mendirikan lebih banyak lagi pada kawasan ini. Hal ini sesuai yang disampaikan pemilik indekos pada Dusun Ngelanjaran Ibu. Animartanti pada observasi wawancara berikut : 
"Kemarin semenjak masyarakat mendengarkan isu pemindahan Fakultas Hukum disini banyak pemilik tanah yang berani langsung mendirikan kost di atas lahan mereka. awalnya lahan mereka di tanam pohon sengon karena masih belum berani mau mendirikan kos. Soalnya takut pada gak laku kamar kostnya. Soalnya disini sepertinya sudah mencukupi jumlah kost." [10].

Isu-isu yang berkembang di masyarakat turut andil dalam proses perkembangan suatu wilayah contohnya perkembangan wilayah dusun-dusun di sekitar UII yang dijelaskan pada sub-bab sebelumnya dengan ditetapkanya peraturan daerah pada suatu wilayah masyarakat secara langsung menanggapinya dengan berbagai cara misalkan dengan membeli lahan di sekitar dusun yang berdekatan secara langsung dengan kampus diyakini akan memberi hasil yang menguntungkan dikarenakan nilai harga jual tanah yang semakin tinggi. peningkatan harga tanah yang paling tinggi adalah (Dusun Lodadi, Dusun Kopatan, Dusun Ngelanjaran) harga tanah pada wilayah ini sudah cukup besar kenaikannya sebelum Kampus UII didirikan. Hal ini dikarenakan masyarakat sudah mengetahui lama sebelum pembangunan kampus.

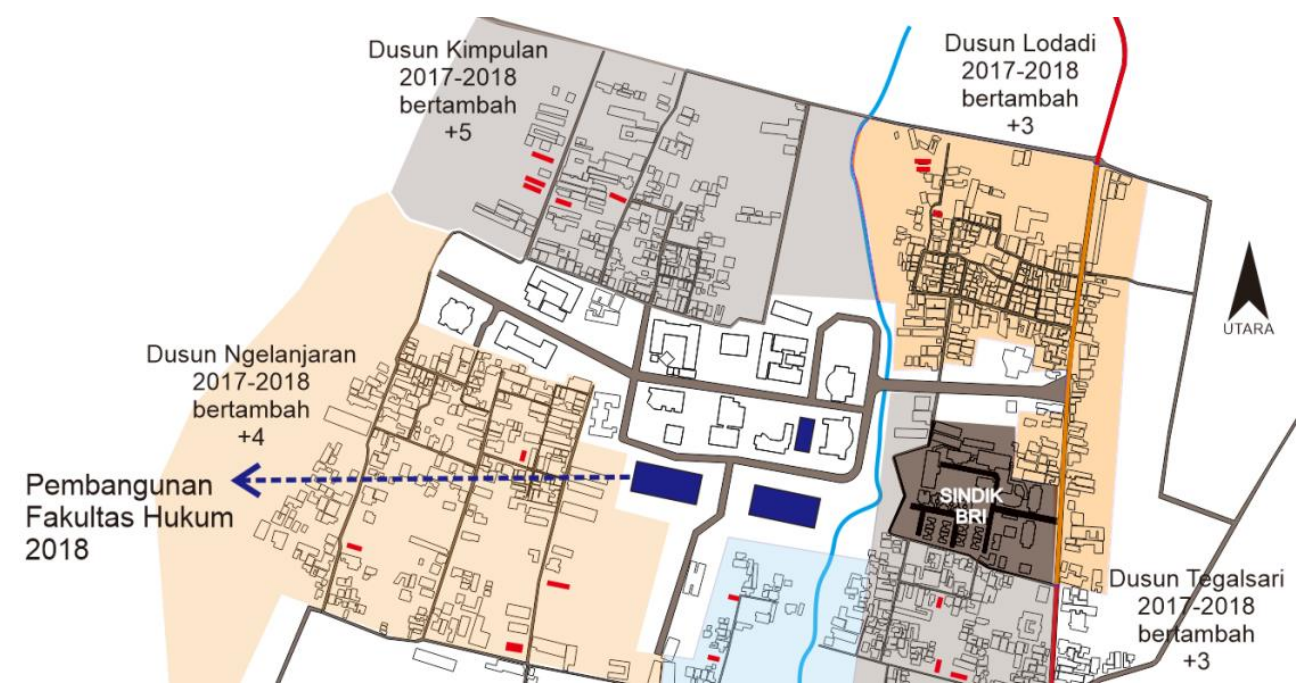

Gambar 8. Peta bertambahnya jumlah hunian sementara (kost) pada tahun 2018.

Bertambahnya jumlah indekos pada wilayah dusun sekitar UII terjadi secara signifikan pada tahun 2018. Hal ini dikarenakan pemindahan lokasi Fakultas Hukum yang sebelumnya berada pada Jalan Tamansiswa pindah ke Kampus Terpadu UII. Penambahan jumlah indekos ini terjadi dikarenakan respon pemilik lahan di sekitar dusun-dusun sekitar UII dimana pemindahan fakultas ini berpotensi penambahan jumlah mahasiswa yang akan menempuh pendidikan di Kampus Terpadu UII. Oleh karena itu pembangunan hunian sementara pada kawasan ini merupakan bisnis yang berpotensi menghasilkan keuntungan. Respon ini dilakukan oleh pemilik lahan di kawasan sekitar dusun ini dimulai dari awal tahun 2017 setelah UII merencanakan pemindahan lokasi Fakultas Hukum ke Kampus Terpadu UII. Penambahan jumlah indekos ini dapat dilihat pada Gambar 8 dimana jumlah yang signifikan terjadi pada Dusun Kimpulan dan Dusun Ngelanjaran dikarenakan Dusun Kimpulan memiliki 
lahan kosong yang lebih banyak dibandingkan Dusun Lodadi yang lebih padat akan permukiman. Penambahan jumlah indekos ini didapatkan dari hasil obsevasi serta overlay peta pada Google Maps tahun 2017-2018. Bertambahnya jumlah indekos pada kawasan ini dikarenakan peluang investasi yang menjanjikan terhadap investor di dalamnya. Data jumlah penambahan dusun ini didapatkan dari masing-masing data yang diperoleh dari masingmasing dusun. Tabel 2 menunjukkan data penambahan jumlah indekos pada dusun sekitar UII.

Tabel 2. Data penambahan jumlah indekos pada tahun 2017-2018.

\begin{tabular}{cccc}
\hline Dusun & $\begin{array}{c}\text { Jumlah } \\
\text { Indekos } \\
\text { Tahun 2017 }\end{array}$ & $\begin{array}{c}\text { Jumlah } \\
\text { Indekos Tahun } \\
2018\end{array}$ & $\begin{array}{c}\text { Jumlah } \\
\text { Penambahan }\end{array}$ \\
\hline Lodadi & 46 & 52 & +6 \\
Ngelanjaran & 38 & 42 & +4 \\
Kimpulan & 32 & 37 & +5 \\
\hline
\end{tabular}

3.3.3. Faktor mahasiswa yang bermukim di dusun-dusun sekitar kampus. Mahasiswa berkontribusi terhadap perkembangan permukiman di sekitar Kampus UII. Dari hasil pemetaan pada sub-bab sebelumnya (hasil survey) terlihat bahwa pola sebaran fasilitas hunian indekos yang terletak pada kawasan Kampus Terpadu UII adalah berbentuk berkelompok serta memadat pada suatu permukiman. Dapat dilihat pada peta sebelumnya hunian indekos lebih cenderung mendekati permukiman warga serta wilayah yang memiliki pelayanan dan jasa. Fasilitas rumah indekos yang paling padat berada pada Dusun Lodadi kemudian disusul dengan Dusun Kopatan dan Dusun Ngelanjaran. Dari hasil pemetaan di atas bahwa ketiga dusun tersebut berbatasan secara langsung dengan Kampus Terpadu UII lebih tepatnya mengelilingi Kampus Terpadu UII. Semakin bertambahnya jumlah mahasiswa Kampus UII selama menempuh masa studi pendidikan menyebabkan masyarakat sekitar kampus menyediakan pelayanan dan jasa kepada mereka. Hal yang terpenting bagi mahasiswa untuk mempertimbangkan tempat tinggalnya adalah jarak serta pelayanan dan jasa yang mencukupi. Semakin lengkap fasilitas pelayanan dan jasanya maka semakin padat suatu permukiman. Hal ini juga disampaikan oleh koresponden Sdr. Aldi (Ngelanjaran) yang menyatakan :

"Saya memilih kost di Ngelanjaran ini dikarenakan dekat sama kampus fasilitas juga lengkap disini ada warung makan, loundry jadi saya ga begitu perlu kendaraan buat ke kampus. Itung" mengurangi beban orangtua"[11].

Jarak antara hunian dan kampus merupakan aspek yang paling penting dalam menentukan rumah indekos bagi mahasiswa sehingga dengan mengetahui jarak tempuh ke kampus maka mahasiswa dapat memperkirakan biaya transportasi yang harus mereka keluarkan. Dari hasil wawancara terhadap mahasiswa maka dapat diketahui semakin dekat jarak dengan kampus maka semakin banyak yang menyewa hunian indekos dan sementara semakin jauh jarak hunian indekos dari kampus maka akan sedikit pula yang akan menyewa serta semakin sedikit yang menyewa. Hal ini dikarenakan faktor lain seperti biaya yang lebih besar 
dikeluarkan oleh mahasiswa jika menggunakan jasa transportasi dan kendaraan bermotor maka akan lebih banyak biaya yang akan mereka keluarkan.

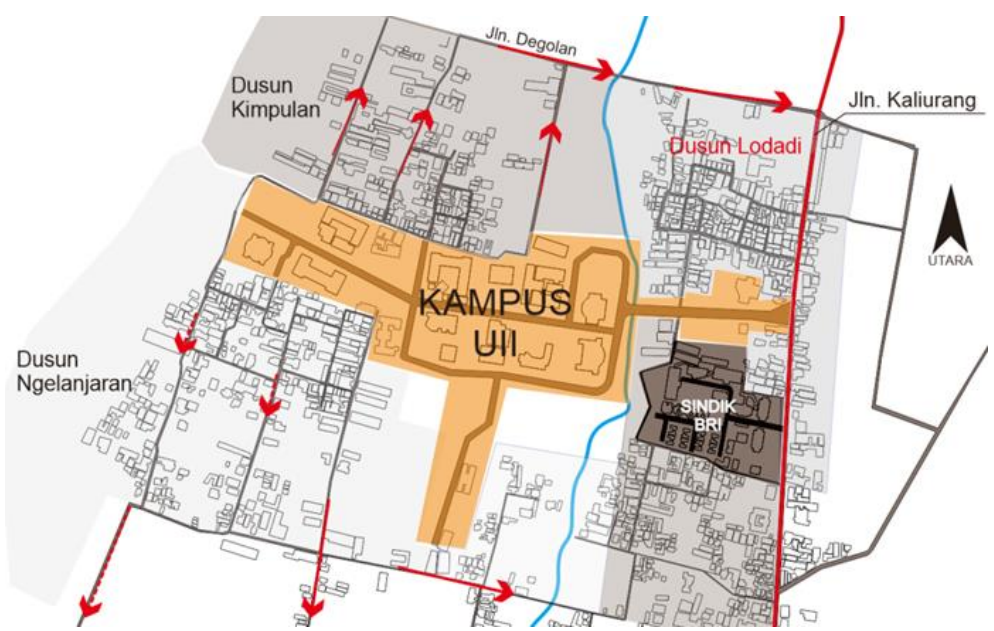

Gambar 9. Peta jalur akses menuju jalan utama Kaliurang km 14,5

Selanjutnya dilihat dari pendapat mereka (mahasiswa) prioritas mereka dalam memilih rumah indekos lebih cenderung kepada tempat yang strategis. Wilayah yang strategis akan membantu mereka untuk menggapai kebutuhan sehari-hari mereka tanpa perlu memikirkan jarak antar hunian mereka, hal ini akan mempermudah mereka dalam pencapaian tujuan mereka. Jarak merupakan prioritas penting bagi seorang mahasiswa untuk memilih lokasi hunian. Semakin dekat jarak dengan kampus maka semakin banyak mahasiswa bermukim disana. Hal ini berkaitan dengan Dusun Lodadi yang semakin padat dikarenakan dusun ini berdekatan dengan pusat pelayanan dan jasa pada poros Jalan Kaliurang Km 14,5 sehingga permintaan jumlah hunian pada kawasan ini terbilang cukup tinggi sehingga menimbulkan kerapatan antar bangunan yang saling berdekatan.

Tabel 3. Rekapitulasi faktor-faktor yang mempengaruhi perubahan penggunaan lahan pada dusun di sekitar UII

\begin{tabular}{|c|c|c|}
\hline No & Faktor yang mempengaruhi & Perubahan yang terjadi \\
\hline 1 & $\begin{array}{l}\text { Keluarnya Izin Lokasi dari Gubemur Kepala } \\
\text { Daerah Istimewa Yogyakarta No.593.82/2238 } \\
\text { tanggal } 30 \text { Desember } 1983 \text { (yang menetapkan } \\
\text { mengeluarkan izin pembangunan kampus) }\end{array}$ & $\begin{array}{l}\text { - } \text { Alih fungsi lahan } \\
\text { - Perubahan aktifitas lahan } \\
\text { - Perubahan aktifitas masyarakat } \\
\text { - } \text { Perubahan harga lahan } \\
\text { - } \quad \text { Terjadinya urbanisasi }\end{array}$ \\
\hline 2 & $\begin{array}{l}\text { Faktor perkembangan kampus UII dan } \\
\text { pemindahan Fakultas Hukum }\end{array}$ & $\begin{array}{l}\text { - Bertambahnya jumlah hunian indekos } \\
\text { - Bertambahnya jumlah unit pelayanan } \\
\text { dan jasa } \\
\text { - Peningkatan harga tanah } \\
\text { - } \text { Kepadatan permukiman yang semakin } \\
\text { tinggi } \\
\text { - } \text { Mempengaruhi Kabupaten Sleman } \\
\text { sebagai kawasan resapan primer }\end{array}$ \\
\hline
\end{tabular}




\begin{tabular}{|c|c|c|}
\hline No & Faktor yang mempengaruhi & Perubahan yang terjadi \\
\hline 3 & $\begin{array}{l}\text { Faktor mahasiswa yang bermukim di sekitar } \\
\text { kampus UII }\end{array}$ & $\begin{array}{l}\text { - Perkembangan permukiman di sekitar } \\
\text { kampus } \\
\text { - Perubahan preferensi mahasiswa untuk } \\
\text { memilih tempat tinggal }\end{array}$ \\
\hline
\end{tabular}

Lynch [9] dalam bukunya Site Planning yang menyatakan bahwa pada saat sekarang adalah periode pertumbuhan cepat dari beragam institusi diantaranya adalah kampus universitas, rumah sakit, unit pemerintahan dan pusat kebudayaan. Salah satunya penunjang perkembangan suatu daerah adalah kampus atau perguruan tinggi yang akan berkembang serta menimbulkan karakter yang kuat di dalamnya. Menurut Lynch [9] perencanaan suatu institusi secara umum memiliki keterkaitan penting antara tapak perencanaan dan tujuan pentingnya dengan kebutuhan nyata akan tempat tinggal dan hubungan antar bagiannya maupun dengan bagian lain dari kota. Alexander dalam Djunaedi [12] berpendapat bahwa universitas merupakan suatu "pasar ide" yang berlokasi di kota tempat masyarakat dapat membeli berbagai macam ide dan mempelajari hal-hal yang menarik perhatian mereka.

Keberadaan sebuah institusi diharapkan berpengaruh terhadap masyarakat dalam dunia pendidikan. Keberadaan kampus juga berdampak terhadap perkembangan kesejahteraan masyarakat sekitarnya. Seperti Ilhami [13] bahwa untuk membentuk titik-titik pertumbuhan baru di sekitar kota salah satunya adalah dengan meletakan kampus di daerah pinggiran kota (area antara kota dan desa) hal ini merupakan salah satu potensi untuk menjadikan suatu daerah menjadi perkotaan. Dengan adanya kampus di daerah pinggiran, terdapat urbanisasi (mahasiswa) dan urbanisasi spasial (berubahnya pemanfaatan ruang). Seiring berkembangnya zaman fungsi rumah masyarakat juga ikut berkembang, pada awalnya berupa tempat tinggal menjadi tempat tinggal beserta usaha. Hal ini sesuai yang katakan masyarakat asli sekitar kampus yang menyatakan bahwa berubahnya fungsi rumah menjadi ganda tidak hanya sebagai hunian melainkan tempat tinggal dan tempat usaha. Hal ini sesuai yang dikatakan Marsoyo [14] mengatakan bahwa kegiatan ekonomi di rumah dapat dipilah menjadi sektor perdagangan, sektor jasa dan industri kecil. Kegiatan menyewakan rumah sebagai tempat tinggal mahasiswa ini merupakan salah satu jenis usaha yang merupakan bagian dari sektor jasa.

Terwujudnya permukiman sebagai bentuk fisik yang mempengaruhi beberapa faktor-faktor salah satunya faktor ekonomi, sosial religi dan kultural yang menentukan perwujudan arsitektur permukiman menjadi teori besar (Grand Theory) dalam penelitian ini. Unsur (faktor) sosiokultural yang paling dekat dengan aransemen lingkungan terbangun adalah aktivitas. Maka perwujudan fisik spasial permukiman berhubungan dengan aktivitas masyarakat. Permukiman merupakan kelompok satuan kediaman manusia pada suatu wilayah berupa bangunan rumah tinggal dan segala fasilitas yang diperlukan untuk menunjang kehidupan penghuninya. Perkembangan spasial permukiman merupakan berkembangnya suatu yang berkaitan dengan tempat dan ruang yang terjadi pada lingkungan permukiman, tempat tinggal, bangunan yang terbentuk karena adanya suatu faktor yang berkembang di lingkungan masyarakat [8]. 


\section{Kesimpulan}

Perkembangan Kampus UII dari awal pembangunan pada tahun 1992 pada Desa Umbulmartani berdampak terhadap kawasan di sekitarnya. Baik secara langsung ataupun tidak langsung. Pembangunan kampus ini berpengaruh terhadap pertumbuhan jumlah pelayanan dan jasa baik itu berupa indekos, cafetaria dan rumah makan pada sekitar kampus tersebut. Pembangunan Kampus Terpadu Universitas Islam Indonesia berdampak positif terhadap peningkatan perekonomian masyarakat asli ataupun pendatang. Peningkatan perekonomian masyarakat tersebut dapat dilihat dari perubahan mata pencaharian masyarakat yang awalnya sebagai petani menjadi pengusaha, sehingga berpengaruh terhadap kehidupan masyarakat lebih baik dari sebelumnya.

Berdasarkan hasil penelitian, diketahui bahwa terdapat tiga faktor yang mempengaruhi perkembangan permukiman di dusun-dusun sekitar kampus terpadu UII, yakni faktor kebijakan pemerintah, faktor perkembangan dan pembangunan Kampus UII, dan faktor mahasiswa yang bermukim di sekitar Kampus UI. Adapun kawasan permukiman yang mengalami perkembangan sebagai dampak dari Kampus UII, yakni Dusun Lodadi, Dusun Kimpulan, dan Dusun Nglanjaran. Ketiga dusun tersebut berbatasan secara langsung dengan Kampus Terpadu UII, atau lebih tepatnya mengelilingi Kampus Terpadu UII. Faktor kebijakan pemerintah berupa izin Lokasi dari Gubemur Kepala Daerah Istimewa Yogyakarta No.593.82/2238 tanggal 30 Desember 1983 (yang menetapkan mengeluarkan izin pembangunan kampus), mempengaruhi terjadinya alih fungsi lahan, perubahan aktivitas lahan, perubahan aktivitas masyarakat, perubahan harga lahan, dan urbanisasi. Faktor perkembangan kampus UII dan pemindahan Fakultas Hukum, mempengaruhi pertambahan jumlah hunian indekos, jumlah unit pelayanan dan jasa, peningkatan harga tanah, peningkatan kepadatan permukiman, dan mempengaruhi peran Kabupaten Sleman sebagai kawasan resapan primer. Faktor mahasiswa yang bermukim di sekitar kampus UII berpengaruh terhadap perkembangan permukiman di sekitar kampus, serta perubahan preferensi mahasiswa untuk memilih tempat tinggal.

\section{Referensi}

[1] Huisman H 1987 Perencanaan Pelayanan dan Pusat Pelayanan Nr VII Regional And Rural Development Planning Series Faculty of Geography Gadjah Mada University

[2] Kustiawan I 1997 Konversi Lahan Pertanian di Pantai Utara Jawa (Jakarta: Prisma)

[3] Anwar A 1993 Dampak Alih Fungsi Lahan Sawah Menjadi Lahan Non-Pertanian Di Sikitar Wilayah Perkotaan Jurnal Perencanaan Wilayah dan Kota 10

[4] Jarwa P 2009 Perkembangan Spasial Desa Umbulmartani Jurnal Teknik Sipil dan Perencanaan DOI: 10.15294/itsp.v17i1.6872

[5] Muslim A 2002 Kajian Perubahan Kepemilikan, Penggunaan dan Harga Tanah di Kawasan Yogyakarta Utara Studi Kasus Empat Belas Dusun di Sekitar Kampus terpadu Universitas Islam Indonesia (UII) Tesis (Yogyakarta: Universitas Gadjah Mada) Diakses dari http://perpustakaan.bappenas.go.id/lontar/file?file=digital/154444-[ Konten ]Konten\%20D562.pdf pada 07-01-2020

[6] Moleong L J 1993 Metode Penelitian Kualitatif (Bandung: PT. Remaja Rosda Karya) 
[7] Sujarto 1985 Beberapa Pengertian tentang Perencanaan Fisik (Jakarta: Bhatara Karya Aksara)

[8] Anonim 17 Febuari 2018 Komunikasi Personal

[9] Lynch K 1997 Site Planning (Cambridge: The Massachusetts Institute of Technology Press)

[10] Animartanti Februari 2018 Komunikasi Personal

[11] Aldi Februari 2018 Komunikasi Personal

[12] Djunaedi A 1997 Campus Planning (Yogyakarta: Universitas Gadjah Mada Press)

[13] Ilhami 1990 Strategi Pembangunan Perkotaan di Indonesia (Surabaya: Usaha Nasional)

[14] Marsoyo A 1993 Perbaikan Perumahan Melalui Home Based Enterprised Forum Perencanaan Pembangunan 